\title{
Effect of nivazol in Nelson's syndrome
}

\author{
Joanna A. Ball, Gareth Williams, Tom H. Yeo and G.F. Joplin
}

Department of Medicine, Royal Postgraduate Medical School, Hammersmith Hospital, London W12 0HS, UK.

\begin{abstract}
Summary: We report the use of nivazol in a patient with Nelson's syndrome. Nivazol was highly effective in reducing ACTH secretion but, contrary to reports of its use in other primates, in our patient nivazol did have systemic glucocorticoid effects.
\end{abstract}

\section{Introduction}

Nelson's syndrome, ${ }^{1}$ comprising a pituitary corticotroph tumour, high plasma adrenocorticotrophic hormone (ACTH) concentrations and hyperpigmentation, develops in up to $80 \%$ of patients following bilateral adrenalectomy for Cushing's disease. ${ }^{2}$ Some cases progress despite attempted hypophysectomy, irradiation or the available medical treatments (cyproheptadine, bromocriptine, and sodium valproate). We have treated one such case with nivazol (SterlingWinthrop Research Institute), a synthetic steroid which reduces ACTH secretion both in vitro from corticotroph tumours, ${ }^{3}$ and in vivo in monkeys without exerting systemic glucocorticoid effects. ${ }^{4}$

\section{Case report}

A 22 year old man with Cushing's disease underwent subtotal adrenalectomy in 1953 and total adrenalectomy in 1956. Two years later, he presented with bitemporal visual loss, 3rd and 4th cranial nerve palsies and hyperpigmentation. He underwent transfrontal hypophysectomy and external beam irradiation for a locally invasive mucoid cell adenoma, but pigmentation progressed despite interstitial ${ }^{90} \mathrm{Y}$ irradiation (1972 and 1974, total dose $200,000 \mathrm{cGy}$ ), and he became severely depressed. ACTH levels remained grossly elevated, with no consistent fall with cyproheptadine $(24 \mathrm{mg} /$ day $)$, sodium valproate $(1500 \mathrm{mg} /$ day $)$ or bromocriptine $(40 \mathrm{mg} /$ day $)$. In 1986 , computed tomographic (CT) scan showed residual pituitary tumour with extensions laterally and into the sphenoid sinus.

Correspondence: Professor G.F. Joplin, Ph.D., F.R.C.P.

Accepted: 20 October 1987
The present study was carried out in hospital in 1986. His usual replacement treatment with hydrocortisone $20 \mathrm{mg}(0700 \mathrm{~h}), 10 \mathrm{mg}(1400 \mathrm{~h})$, $10 \mathrm{mg}(1800 \mathrm{~h})$, fludrocortisone $0.1 \mathrm{mg}$ alternate days, thyroxine $200 \mu \mathrm{g}$ daily and testosterone undecanoate $40 \mathrm{mg}$ t.d.s., was continued. Fortyeight hour plasma cortisol and ACTH profiles (4hourly samples) were measured before nivazol treatment, after 1 week of low-dose oral nivazol $(200 \mathrm{mg}$ at 0800 and $2000 \mathrm{~h}$ ) and after 6 weeks of high-dose nivazol $(400 \mathrm{mg}$ at 0800 and $2000 \mathrm{~h}$ ). Blood samples for ACTH assay were collected into plastic lithiumheparin tubes containing aprotinin $(400 \mathrm{kIU} / \mathrm{ml}$ blood). Plasma was separated immediately by centrifugation at $4^{\circ} \mathrm{C}$, extracted on to Vycor glass and ACTH was measured by double-antibody radioimmunoassay. The intra- and inter-assay coefficients of variation were $10 \%$ at $500 \mathrm{ng} / \mathrm{l}$ and $<20 \%$ at $700 \mathrm{ng} / \mathrm{l}$.

Serial photographs showed strikingly reduced skin pigmentation after both low and high dosages, being evident within 2 weeks. Nivazol treatment also significantly reduced mean plasma ACTH levels from $4244 \pm 1093$ (s.e.m.) ng/l (pre-treatment) to $1198 \pm 257 \mathrm{ng} / 1$ with low dosage $(P<0.02$ by paired $t$-test, $n=12$ ) and still further to $849 \pm 123 \mathrm{ng} / 1 \quad(P<0.01, n=12))$ with high dosage (Figure 1). Mean cortisol concentrations were unchanged (pre-treatment, $425 \pm 96 \mathrm{nmol} / 1$; low dosage, $455 \pm 95 \mathrm{nmol} / \mathrm{l}$; high dosage, $559 \pm 107 \mathrm{nmol} / \mathrm{l}$ ). Pituitary tomography showed no change in sellar size over the treatment period of 8 months. Biochemical and haematological indices were unchanged.

Nivazol was initially well tolerated and ACTH levels fell to the lowest values ever recorded in this patient $(333 \pm 147 \mathrm{ng} / \mathrm{l})$, but after 10 weeks the patient developed facial plethora, weight gain, proximal myopathy and depression. These Cushingoid features remained for a further 10

(C) The Fellowship of Postgraduate Medicine, 1988 


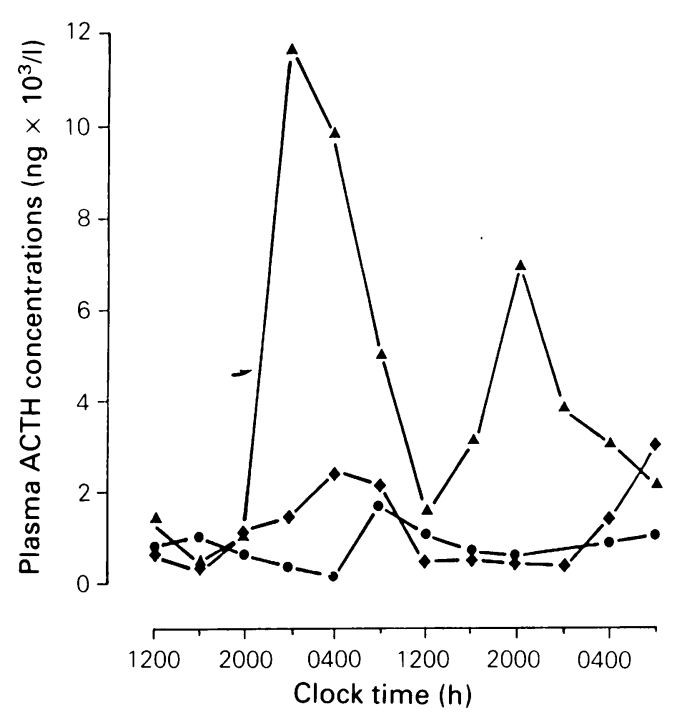

Figure 1 Forty-eight hour profile of plasma ACTH concentrations before and during nivazol treatment; $\Delta$, control period; $\diamond$, after one week nivazol $400 \mathrm{mg} / \mathrm{day}$; , after 6 weeks nivazol $800 \mathrm{mg} /$ day. Normal range for plasma ACTH: $0800 \mathrm{~h}<80 \mathrm{ng} / \mathrm{l}$; $2400 \mathrm{~h}<10 \mathrm{ng} / \mathrm{l}$.

weeks despite reducing nivazol to $200 \mathrm{mg}$ twice daily and hydrocortisone to $5 \mathrm{mg}$ daily, but resolved after withdrawal of nivazol.

\section{References}

1. Rees, J.R. Cushing's syndrome with pituitary tumour and pigmentation. Proc R Soc Med 1959, 52: 256-257.

2. Manolas, K.J., Farmer, H.M., Wilson, H.K. et al. The pituitary fossa before and after adrenalectomy for Cushing's syndrome. World J Surg 1984, 8: 374-387.

3. Adams, E.F., Ashby, M.J. Burrin, J. et al. Effect of nivazol on ACTH secretion by human pituitary corticotrophic tumours in cell culture. Clin Endocrinol 1985, 22: 631-638.

\section{Discussion}

Nivazol was clearly highly effective in decreasing plasma ACTH concentrations and pigmentation. Its mechanism of action is probably similar to that of hydrocortisone. Both steroids directly inhibit in vitro ACTH secretion from corticotroph tumour cells removed from patients with Nelson's syndrome and block stimulation of ACTH release by ovine corticotrophin releasing factor and arginine vasopressin. ${ }^{3}$ As therapeutic plasma nivazol levels are lower than those effective in vitro, nivazol (like hydrocortisone) may also act on the hypothalamus. The unchanged cortisol profiles argue against an effect on hydrocortisone metabolism. We cannot assess whether nivazol had additional tumour stabilizing or shrinkage effects. Nivazol had significant Cushingoid side effects in our patient, even though proportionately much higher doses $(1 \mathrm{~g} /$ day $)$ in monkeys suppressed the hypothalamic-pituitary adrenal axis without exerting peripheral glucocorticoid effects. ${ }^{4}$ It remains to be investigated whether dosages of $<400 \mathrm{mg}$ /day may be therapeutically useful without causing these side effects.

\section{Acknowledgement}

We would like to thank Karen F. Stringer, B.Sc., Project Leader, Sterling-Winthrop Research and Development, Sterling-Winthrop House, Surbiton, Surrey, for the supply of nivazol and for helpful discussions.

4. Schane, H.P., Harding, H.R., Creange, J.E., Bolton, I., Castracane, V.D. \& Snyder, B.W. Nivazol: a glucocorticoid in rats with only hypothalamic-pituitaryadrenal inhibiting activity in primates. Endocrinology 1984, 114: 1983-1989.

5. Rees, L.H., Cook, D.M., Kendall, J.W. et al. A radioimmunoassay for rat plasma ACTH. Endocrinology 1971, 89: 254-261. 